\title{
Pharmacognostic evaluation of Terminalia chebula standard extracts and finished products
}

\author{
Conjeevaram J. Gunasekar ${ }^{1}$, Imad A. Abu-Yousef ${ }^{2}$, Amin F. Majdalawieh ${ }^{2, *}$ and \\ Srinivasan Narasimhan ${ }^{1}$ \\ ${ }^{1}$ Asthagiri Herbal Research Foundation, 162A, Perungudi Industrial Estate, Perungudi, Chennai, India 600096 \\ ${ }^{2}$ Department of Biology, Chemistry, and Environmental Sciences, College of Arts and Sciences, American \\ University of Sharjah, P.O. Box 26666, Sharjah, United Arab Emirates
}

\begin{abstract}
The different commercial samples of Terminalia chebula (T. chebula) standard extracts and finished products were taken for elemental analysis studies and were evaluated by ICP-OES and compared with standard reference data. Trace elements are naturally occurring and its daily requirement as dietary supplement form is only a few milligrams and even micrograms. They are categorized as essential and non-essential, and that is based upon their biological action, diseases that occur due to their deficiency and toxicity due to overdose. Use of herbal medicines is now increasing worldwide because of their minimal side effects. In general, Haritaki (T. chebula) acts as a blood purifier and prevents haemorrhage. It is also used as an internal cleanser by removing harmful toxins and excess fats out of the body. It can strengthen the hair roots and enriches hair color. The elements were determined quantitatively using the modern technique of ICP-OES. The extracts undertaken for this study contains $\mathrm{Ca}$ as a primary elemental content, and its concentration is found to be as high as $144 \mathrm{mg} / \mathrm{kg}$ in comparison with other macro elements. $\mathrm{Ca}$ helps to overcome the problems of high blood pressure, heart attack, premenstrual syndrome, and colon cancer, besides its ability to keep the bones healthy and to reduce the risk of osteoporosis. Other essential elements such as Fe (2.0732 mg/kg), Zn (1.0235 mg/kg), and Mn $(0.2500 \mathrm{mg} / \mathrm{kg})$ were also present but not to an appreciable amount in the extracts of $T$. chebula. It was concluded that due to soil nature, climatic condition, time of harvest could be a detrimental factor while reviewing the elemental profile.
\end{abstract}

Keywords: $T$. chebula, microwave digestion, ICP-OES, trace elements.

\section{Introduction}

Ayurvedic is an ancient tradition for about 5,000 years old practice and deep-rooted in the earlier civilization of Indian culture ${ }^{1}$. According to the World Health Organization (WHO), about $80 \%$ of the world population depends mainly on plant-based traditional medicine for their primary healthcare requirement ${ }^{2}$ When screening a number of herbal medicinal plants, scientists were discovered that $T$. chebula (Combretaceae) is one of the most revered medicinal plants, possesses several medicinal values due to the presence of many kinds of phytochemical constituents. T. chebula has been extensively used in ayurvedic, Unani \& homoeopathic medicine and has become the cynosure of modern medicine ${ }^{3} T$. chebula possesses a wide variety of activities like antimicrobial ${ }^{4}$, antioxidant ${ }^{5}$, anti-viral ${ }^{6}$, anticarcinogenic ${ }^{7}$, hypocholesterolemic ${ }^{8}$, radioprotective $^{9}$, anti-spasmodic and anti-purgative ${ }^{10}$.

The phytochemicals present in $T$. chebula are polyphenols, terpene, anthocyanins, flavonoids, alkaloids, and glycosides. It is used as a natural cleanser of the digestive system. It improves the functioning of liver, spleen and colon and hence it is widely used as a digestive tonic. From some research studies reveals that the oil in the kernel of $T$. chebula contain certain substances that induce the motility of the gastrointestinal tract ${ }^{11}$ This action was similar to that of castor oil. It is also used in combination with two more herbal extracts to prepare a formulation that is popularly known as Triphala. This formulation is used for enhancing body immunity. T. chebula contains appreciable amounts of tannins, which possess antiseptic and healing properties and hence, it is widely used externally for curing chronic ulcers, wounds, and piles ${ }^{12-15}$.

It has purgative properties ${ }^{16}$. Fine powder of T. chebula extracts is used in dental preparations ${ }^{17,18}$. T. chebula possesses anti-bacterial ${ }^{19}$, anti-cancer ${ }^{20}$, anti-caries ${ }^{21,22}$, antimutagenic potential ${ }^{23}$, and it inhibits local anaphylaxis ${ }^{24}$. The fruit is used for it mild laxative, alterative, and anti-spasmodic effects. 
T. chebula is useful for inducing appetite, as a digestive aid, liver stimulant and as gastrointestinal pro-kinetic agent ${ }^{25-27}$. It is useful in treating skin disorders with discharges like allergies, urticaria and other erythematous disorders ${ }^{28-30}$. T. chebula Retz (Combretaceae) has a legendary reputation as a male contraceptive ${ }^{31}$.

The present study has been undertaken with four samples of standard extracts procured from different geographical locations of India, and three samples of domestic market products containing $T$. chebula as formulated medicine were evaluated for their essential and trace elements contents and compared to NIST standard.

\section{Material and Methods}

\section{Collection of Samples}

Well-matured, healthy and dried fruits of $T$. chebula were collected from different locations in India (April to June).

Site I: Tambaram, India $\left(12^{\circ} 55^{\prime} 22.4940^{\prime \prime} \mathrm{N}\right.$ and $80^{\circ} 7^{\prime} 38.8452^{\prime \prime} \mathrm{E}$ )

Site II: Bangalore, India $\left(12.9716^{\circ} \mathrm{N}\right.$ and $77.5946^{\circ}$ E)

Site III: Coimbatore, India $\left(11^{\circ} 0^{\prime} 16.4016^{\prime \prime} \mathrm{N}\right.$ and $76^{\circ}$ 57' 41.8752" E)

Site IV: Nagpur, India $\left(21^{\circ} 8^{\prime} 47.8788^{\prime \prime} \mathrm{N}\right.$ and $79^{\circ} 5^{\prime}$ $19.8960 " \mathrm{E})$

Standard T. chebula extracts (TCEs):

\begin{tabular}{|c|c|c|c|}
\hline Code & Source & Mass & Volume \\
\hline TCE-1 & Tambaram & $1.0170 \mathrm{~g}$ & $50 \mathrm{ml}$ \\
\hline TCE-2 & Bangalore & $1.0276 \mathrm{~g}$ & $50 \mathrm{ml}$ \\
\hline TCE-3 & Coimbatore & $1.0143 \mathrm{~g}$ & $50 \mathrm{ml}$ \\
\hline TCE-4 & Nagpur & $1.0198 \mathrm{~g}$ & $50 \mathrm{ml}$ \\
\hline
\end{tabular}

Finished products consisting of $T$. chebula as a major ingredient (TCFs):

\begin{tabular}{|l|l|l|l|}
\hline Code & Source & Mass & Volume \\
\hline TCF-1 & Chennai & $1.0303 \mathrm{~g}$ & $50 \mathrm{ml}$ \\
\hline TCF-2 & Coimbatore & $1.0763 \mathrm{~g}$ & $50 \mathrm{ml}$ \\
\hline TCF-3 & Bangalore & $1.0414 \mathrm{~g}$ & $50 \mathrm{ml}$ \\
\hline
\end{tabular}

\section{Solutions and Reagents}

Standard solutions were prepared by diluting individual metal standard solution $(1,000 \mu \mathrm{g} / \mathrm{ml})$ procured from BDH Middle East L.L.C. with $1 \mathrm{M}$ $\mathrm{HNO}_{3}$. The plant extract was incinerated in a muffle furnace and made into ash, which was then digested with $\mathrm{HNO}_{3}+30 \% \mathrm{H}_{2} \mathrm{O}_{2}$ and prepared the solutions.

\section{Preparation of Sample by Microwave Digestion Method}

Microwave digestion involves the application of electromagnetic radiation with the frequency of 2,450 $\mathrm{MHz}$ to dissolve the samples ${ }^{32}$. The microwaves interact with polar molecules and induce alignment of the molecular dipole moment with the microwave field. While field constantly changes and causing the molecular rotation and make intermolecular collisions occurs among themselves and heat evolves. Consequently, the rate of microwave digestion is dependent on the coupling efficiency of microwaves with the digestion acids. Microwave technology is often recommended for safety considerations. They are also programmable and can accommodate large numbers of samples. $T$. chebula extract was weighed accurately and transferred into seven fluorocarbon microwave vessels and added with $10 \mathrm{ml}$ concentrated $\mathrm{HNO}_{3}$ to each of it. Sealed the vessel and placed correctly in the microwave system (Anton par Microwave digester). A blank sample was also prepared simultaneously by placing $10 \mathrm{ml}$ of concentrated $\mathrm{HNO}_{3}$ acid in one of the empty fluorocarbon microwave vessels and placed it in the microwave system after sealing it tightly. All the samples and blank were digested at $175^{\circ} \mathrm{C}$ for 10 minutes. After cooling it to a sufficient time, carefully uncapped and vented each vessel in a fume cupboard. Contents of each vessel then transferred to $50 \mathrm{ml}$ volumetric flask and made up to the mark with Mille-Q water.

\section{Preparation of Reference Standard Solution}

Standard solutions of each element were separately prepared using reference standard metal solutions. The procedure followed was as per the Analysis Guidebook of Shimadzu Solutions for Science. The solutions prepared were placed in tightly capped plastic bottles and used within a day of their preparation.

\section{Preparation of Reagent Blank Solution}

About $10 \mathrm{ml}$ of concentrated Nitric acid and $2 \mathrm{ml}$ of $30 \%$ hydrogen peroxide were quantitatively added into $50 \mathrm{ml}$ volumetric flask and diluted with deionized water to the mark. These solutions were served as blank solution.

\section{Determination of Elements Concentration}

Elemental profile of $T$. chebula was determined quantitatively by Inductively Coupled Plasma Optical Emission Spectroscopy (ICP-OES) (VARIAN INC. - liberty series, axially viewed plasma, following type ICP-OES spectrometer, wavelength range 189-940 $\mathrm{nm}$ ). Using standard references, the calibration curves were obtained for all the elements. The sample solutions were adequately diluted to keep the absorbance in the linear range of measurement.

\section{Statistical Analysis}

All assays were carried out in triplicates and values were obtained by calculating the average of five experiments. Data are presented as mean \pm SEM. 
Standard Error of the Mean (SEM): if the parameter or the statistic is the mean, it is called the standard error of the mean (SEM).

The SEM is calculated by dividing the $\operatorname{SD}(\boldsymbol{\sigma})$ by the square root of $n$ (number of samples).

The formula to calculate the standard deviation $(\sigma)$ :

$\sigma=\sqrt{ }\left[\sum(x-\text { mean })^{2} / n\right]$

$x=$ data point

$n=$ number of samples

The formula to calculate SEM:

$\mathrm{SEM}=\sigma / \sqrt{ } n$

\section{Results and Discussion}

Many ayurvedic preparations were successful in treating various diseases, but still, there is no concrete evidence in understanding the precise molecular mechanism. The pharmacological action of most of the plants could be usually focused on its organic, but not its inorganic, content. New research has now focused on the inorganic contents of herbal plants due to the presence of certain trace elements in a bioavailable form. A direct link between the healing ability and the role of trace elements in herbal plants are yet to be proven, and such studies are critical in understanding their pharmacological activities. To determine the trace elements more accurately, techniques like ICP-OES and Atomic Absorption Spectrophotometer (AAS) are a better choice because of their multi-elemental detection capability over a wide range of lower concentration, their blank-free nature, and minimum sample preparation ${ }^{33}$.
The preparation procedure must ensure that simultaneous quantitative mineralization and dissolution by the use of appropriate chemical reagents and by physical means. Incomplete dissolution could cause poor recoveries for many elements due to the presence of silicates, especially those relatively abundant in plant body and partly associated with silicates. Based on the data in the literature, from this study, we found that the recovery of $\mathrm{Al}, \mathrm{Fe}$, and $\mathrm{B}$ is feeble in detection. After the preparation procedure applied in this work, the sample matrix was largely simplified, and the resulting solutions were clear, colorless and odorless with no observed residue with complete dissolution was achieved in most cases.

Concerning Atomic Emission Spectroscopic (AES) analysis, no particular precautions have to be taken if the measured concentrations satisfy the principal criteria (sensitivity, detection limits, working range) and if possible interfering substances should be under control. At optimal plasma condition, all the measurements were made. ICP-AES is mainly used for quantitative measurement of various elements in ppm level concentration.

The entire procedure starting from mineralization, dissolution and measurements were all validated by using AOAS method and compared with CRM (NIST 1573a - Tomato Leaves). It is found that the values obtained from the analysis are very close to the CRM values. \% of recovery is also given in Table 1.

Table 1. Results of CRM (NIST 1573a - Tomato Leaves) in ppm (mg/kg). Values are in \% for Ca.

\begin{tabular}{|c|c|c|c|}
\hline Element & Found & Certified Value & $\begin{array}{c}\text { Recovery Values } \\
(\%)\end{array}$ \\
\hline $\mathbf{C u}$ & 7.55 & $4.70 \pm 0.14$ & 160.6 \\
\hline $\mathbf{Z n}$ & 36.43 & $30.9 \pm 0.70$ & 117.9 \\
\hline $\mathbf{M n}$ & 225.8 & $246 \pm 8.00$ & 91.8 \\
\hline $\mathbf{C o}$ & 304.00 & $368 \pm 7.00$ & 82.6 \\
\hline $\mathbf{C r}$ & 0.64 & $0.57 \pm 0.04$ & 112.3 \\
\hline $\mathbf{N i}$ & 2.23 & $1.99 \pm 0.06$ & 112.2 \\
\hline $\mathbf{P b}$ & 0.90 & $1.59 \pm 0.04$ & 56.60 \\
\hline $\mathbf{C a}$ & 1.04 & Not available & 101 \\
\hline $\mathbf{C d}$ & $5.1 \%$ & $5.05 \pm 0.09 \%$ & 88.03 \\
\hline $\mathbf{K}$ & 526.4 & $598 \pm 2.00$ & 87.5 \\
\hline $\mathbf{N a}$ & 1.33 & $1.52 \pm 0.03$ & 91.1 \\
\hline
\end{tabular}

For statistical analysis, regression analysis and SEM analysis were performed. The correlation coefficients (R) were determined, and an external calibration was carried out. The correlation coefficients were found in the range of 0.9981-0.9999. Table 2 and Figures 1-4 summarize the results of the elemental analysis of $T$. chebula aqueous extracts (TCE-1, TCE-2, TCE-3, and TCE-4). Table 3 and Figures 5-8 summarize the results of the elemental analysis of $T$. chebula-containing finished products (TCF-1, TCF-2, and TCF-3). 
The data in Table 2 indicate that the medicinal plant extract contains macro, micro, trace and toxic elements in various levels of concentrations. All the elements were analyzed by ICP-OES technique by measuring the emission of each element at its resonance wavelength. The nature of soil, the place where the plants were cultivated, and the complex nature of botanical structures are the essential factors that contributed to variation in concentration of each element. Other considerations leading to the variations in the elemental composition include environmental factors such as water and climatic conditions, as well as the use of fertilizers and irrigation water.

The active constituents of the medicinal plants are the metabolic products of the plant cells. Several trace elements play an essential role in metabolism. These elements are called essential.

The elements play both curative and preventive roles in combating diseases ${ }^{34}$. There is a vast scope to exploit the preventive medicinal aspects of various elements.

Table 2. Elemental composition of $T$. chebula aqueous extracts (TCE-1, TCE-2, TCE-3, and TCE-4).

\begin{tabular}{|c|c|c|c|c|}
\hline Element & TCE-1 (mg/kg) & TCE-2 (mg/kg) & TCE- 3 (mg/kg) & TCE- 4 (mg/kg) \\
\hline & & \multicolumn{2}{|l|}{ Macro Elements } & \\
\hline $\mathbf{C a}$ & $162.50 \pm 0.20$ & $132.500 \pm 0.100$ & $128.560 \pm 0.080$ & $153.740 \pm 0.180$ \\
\hline $\mathbf{N a}$ & $87.106 \pm 0.04$ & $68.000 \pm 0.070$ & $70.605 \pm 0.070$ & $83.675 \pm 0.110$ \\
\hline Mg & $36.200 \pm 0.324$ & $34.300 \pm 0.280$ & $34.821 \pm 0.292$ & $35.345 \pm 0.312$ \\
\hline \multirow[t]{2}{*}{$\mathbf{K}$} & $113.60 \pm 0.25$ & $119.000 \pm 0.370$ & $94.960 \pm 0.790$ & $105.360 \pm 0.540$ \\
\hline & & Micro Elements & & \\
\hline Al & $11.713 \pm 0.008$ & $8.6000 \pm 0.003$ & $14.097 \pm 0.015$ & $12.874 \pm 0.0110$ \\
\hline B & $0.4830 \pm 0.0096$ & $0.5789 \pm 0.0071$ & $0.3534 \pm 0.0082$ & $0.4267 \pm 0.0105$ \\
\hline $\mathbf{B a}$ & $3.7100 \pm 0.0053$ & $3.6330 \pm 0.0047$ & $3.6759 \pm 0.0051$ & $3.6528 \pm 0.0032$ \\
\hline $\mathbf{B i}$ & $0.1150 \pm 0.0123$ & $0.9000 \pm 0.0095$ & $0.1074 \pm 0.0104$ & $0.1123 \pm 0.0117$ \\
\hline Cd & $0.0060 \pm 0.0015$ & $0.0030 \pm 0.0008$ & $0.0030 \pm 0.0008$ & $0.0043 \pm 0.0012$ \\
\hline Co & $0.0220 \pm 0$ & $0.0567 \pm 0.010$ & $0.0200 \pm 0.008$ & $0.0214 \pm 0.0050$ \\
\hline $\mathrm{Cr}$ & $0.2000 \pm 0.0073$ & $0.7076 \pm 0.0243$ & $0.3478 \pm 0.0115$ & $0.2543 \pm 0.0083$ \\
\hline $\mathbf{C u}$ & $1.8202 \pm 0.0243$ & $1.7454 \pm 0.0191$ & $1.696 \pm 0.0153$ & $1.7453 \pm 0.0189$ \\
\hline $\mathrm{Fe}$ & $2.0205 \pm 0.0073$ & $2.3300 \pm 0.0094$ & $1.9110 \pm 0.0061$ & $2.0438 \pm 0.0102$ \\
\hline $\mathbf{L i}$ & $0.0400 \pm 0.0081$ & $0.0395 \pm 0.0077$ & $0.0433 \pm 0.0118$ & $0.0424 \pm 0.0109$ \\
\hline Mn & $0.2850 \pm 0.0123$ & $0.2400 \pm 0.0111$ & $0.2390 \pm 0.0107$ & $0.2543 \pm 0.0118$ \\
\hline Mo & $0.0023 \pm 0.0005$ & $0.0046 \pm 0.0012$ & $0.0018 \pm 0.0003$ & $0.0034 \pm 0.0008$ \\
\hline $\mathbf{N i}$ & $0.4238 \pm 0.0031$ & $0.4960 \pm 0.0052$ & $0.3578 \pm 0.0017$ & $0.4327 \pm 0.0036$ \\
\hline $\mathbf{P}$ & $3.1064 \pm 0.0097$ & $2.9412 \pm 0.0073$ & $3.0435 \pm 0.0081$ & $3.1230 \pm 0.0103$ \\
\hline $\mathbf{P b}$ & $0.6874 \pm 0.0069$ & $0.6754 \pm 0.0052$ & $0.6323 \pm 0.0029$ & $0.6824 \pm 0.0061$ \\
\hline $\mathbf{R b}$ & $0.0305 \pm 0.009$ & $0.0976 \pm 0.019$ & $0.0876 \pm 0.017$ & $0.0326 \pm 0.0110$ \\
\hline Se & $0.2130 \pm 0.007$ & $0.2436 \pm 0.016$ & $0.2324 \pm 0.012$ & $0.2254 \pm 0.0090$ \\
\hline $\mathbf{S i}$ & $3.0524 \pm 0.0054$ & $2.9348 \pm 0.0048$ & $3.0754 \pm 0.0059$ & $3.1463 \pm 0.0065$ \\
\hline Sn & $0.0193 \pm 0.0007$ & $0.0204 \pm 0.0011$ & $0.0198 \pm 0.0009$ & $0.0197 \pm 0.0009$ \\
\hline $\mathrm{Sr}$ & $3.5102 \pm 0.0071$ & $3.5234 \pm 0.0078$ & $3.5765 \pm 0.0089$ & $3.5268 \pm 0.0079$ \\
\hline Te & $0.9514 \pm 0.0049$ & $0.9668 \pm 0.0067$ & $0.9576 \pm 0.0054$ & $0.9534 \pm 0.0051$ \\
\hline $\mathbf{T i}$ & $0.0773 \pm 0.0009$ & $0.0745 \pm 0.0006$ & $0.0721 \pm 0.0004$ & $0.0769 \pm 0.0008$ \\
\hline V & $0.0269 \pm 0.0007$ & $0.0276 \pm 0.0009$ & $0.0265 \pm 0.0005$ & $0.0263 \pm 0.0004$ \\
\hline Zn & $1.0239 \pm 0.0032$ & $1.0275 \pm 0.0049$ & $1.0269 \pm 0.0045$ & $1.0235 \pm 0.0033$ \\
\hline
\end{tabular}


Table 3. Elemental composition of T. chebula finished products (TCF-1, TCF-2, and TCF-3).

\begin{tabular}{|c|c|c|c|}
\hline Elements & TCF-1 (mg/kg) & TCF-2 (mg/kg) & TCF-3 (mg/kg) \\
\hline \multicolumn{4}{|c|}{ Macro Elements } \\
\hline $\mathbf{C a}$ & $543.35 \pm 0.13$ & $549.45 \pm 0.17$ & $587.55 \pm 0.570$ \\
\hline $\mathbf{N a}$ & $40.480 \pm 0.110$ & $45.300 \pm 0.095$ & $42.390 \pm 0.065$ \\
\hline Mg & $57.106 \pm 0.040$ & $53.560 \pm 0.018$ & $55.879 \pm 0.028$ \\
\hline \multirow[t]{2}{*}{$\mathbf{K}$} & $634.19 \pm 0.06$ & $637.07 \pm 0.36$ & $647.28 \pm 0.53$ \\
\hline & & Micro Elements & \\
\hline Al & $1.7135 \pm 0.0038$ & $1.6000 \pm 0.0023$ & $1.4097 \pm 0.0017$ \\
\hline $\mathbf{B}$ & $0.2830 \pm 0.0023$ & $0.1789 \pm 0.0009$ & $0.1534 \pm 0.0005$ \\
\hline $\mathbf{B a}$ & $1.7100 \pm 0.0046$ & $1.6330 \pm 0.0027$ & $1.6759 \pm 0.0033$ \\
\hline $\mathbf{B i}$ & $0.0150 \pm 0.0006$ & $0.0400 \pm 0.0014$ & $0.0174 \pm 0.0008$ \\
\hline Cd & $0.0010 \pm 0.0002$ & $0.0020 \pm 0.0004$ & $0.0020 \pm 0.0004$ \\
\hline Co & $0.0220 \pm 0.0013$ & $0.0567 \pm 0.0032$ & $0.0200 \pm 0.0010$ \\
\hline $\mathrm{Cr}$ & $0.8000 \pm 0.0021$ & $0.7076 \pm 0.0008$ & $0.7478 \pm 0.0013$ \\
\hline $\mathbf{C u}$ & $1.4202 \pm 0.0043$ & $1.3654 \pm 0.0037$ & $1.4960 \pm 0.0052$ \\
\hline $\mathbf{F e}$ & $4.0205 \pm 0.0011$ & $4.3300 \pm 0.0036$ & $4.9110 \pm 0.0087$ \\
\hline $\mathbf{L i}$ & $0.0200 \pm 0.0007$ & $0.0195 \pm 0.0006$ & $0.0233 \pm 0.0009$ \\
\hline Mn & $0.5850 \pm 0.0034$ & $0.6400 \pm 0.0046$ & $0.5390 \pm 0.0023$ \\
\hline Mo & $0.0012 \pm 0.0002$ & $0.0036 \pm 0.0008$ & $0.0018 \pm 0.0005$ \\
\hline $\mathbf{N i}$ & $2.1064 \pm 0.0023$ & $1.9412 \pm 0.0019$ & $3.0435 \pm 0.0041$ \\
\hline $\mathbf{P}$ & $0.6328 \pm 0.0104$ & $0.5259 \pm 0.0065$ & $0.4532 \pm 0.0032$ \\
\hline $\mathbf{P b}$ & $0.8765 \pm 0.0027$ & $0.7676 \pm 0.0013$ & $0.8524 \pm 0.0021$ \\
\hline $\mathbf{S i}$ & $0.1436 \pm 0.0018$ & $0.1324 \pm 0.0015$ & $0.0993 \pm 0.0008$ \\
\hline Sn & $0.0114 \pm 0.0004$ & $0.0146 \pm 0.0011$ & $0.0124 \pm 0.0006$ \\
\hline $\mathrm{Sr}$ & $1.9348 \pm 0.0045$ & $2.0754 \pm 0.0054$ & $1.9510 \pm 0.0048$ \\
\hline Te & $0.7432 \pm 0.0026$ & $0.6765 \pm 0.0013$ & $0.7773 \pm 0.0033$ \\
\hline $\mathbf{T i}$ & $0.0345 \pm 0.0007$ & $0.0344 \pm 0.0007$ & $0.039 \pm 0.0008$ \\
\hline $\mathbf{V}$ & $0.0145 \pm 0.0009$ & $0.0121 \pm 0.0004$ & $0.0139 \pm 0.0006$ \\
\hline Zn & $3.0276 \pm 0.0011$ & $3.5265 \pm 0.0035$ & $3.9765 \pm 0.0043$ \\
\hline
\end{tabular}

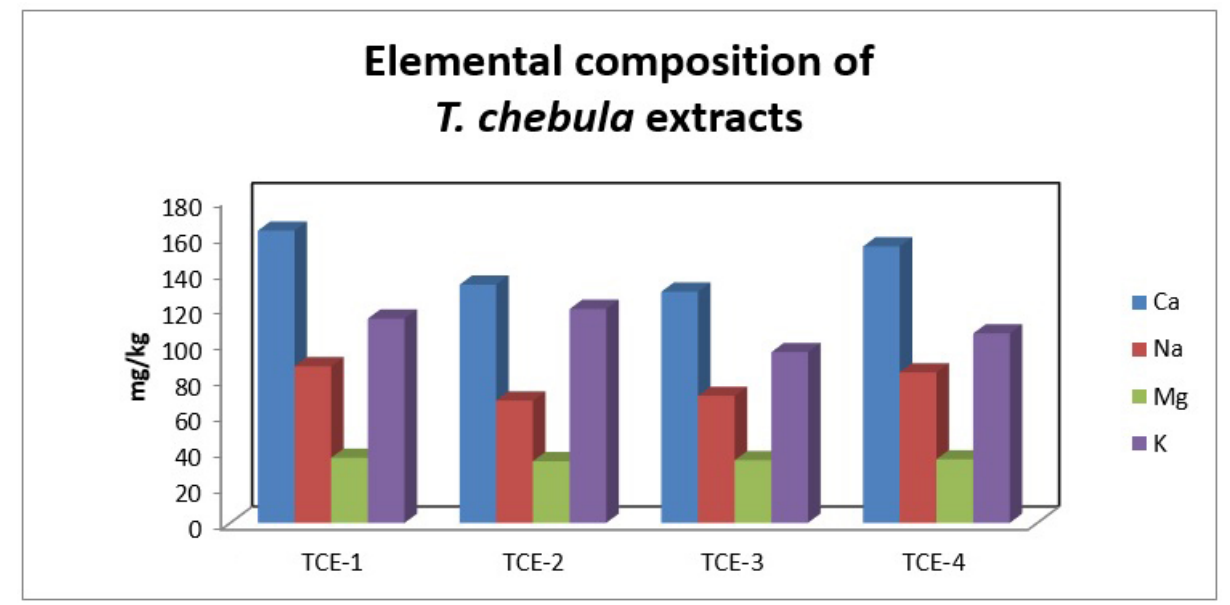

Figure 1. Elemental composition of T. chebula extracts (TCE-1, TCE-2, TCE-3, and TCE-4) [Ca, $\mathrm{Na}, \mathrm{Mg}$, and $\mathrm{K}]$. 
Calcium (Ca) is a macro element and found in abundant quantities in the $T$. chebula extract. The average concentration $\mathrm{Ca}$ found to be $144.3 \mathrm{mg} / \mathrm{kg}$ in $T$. chebula aqueous extract. The values are ranging from 128.56 to $162.5 \mathrm{mg} / \mathrm{kg}$ for samples TCE-1 to TCE-4. To overcome the problems of high blood pressure, heart attack, premenstrual syndrome, colon cancer and keeping the bones healthy and reduces the risks of osteoporosis in old age calcium element plays a vital role in those diseases ${ }^{35,36}$.

Magnesium ( $\mathrm{Mg}$ ) improves insulin sensitivity, protects against diabetes and its complications and reduces the blood pressure 37,38 . The average concentration $\mathrm{Mg}$ was $35.2 \mathrm{mg} / \mathrm{kg}$ in $T$. chebula aqueous extract. The range of values for $\mathrm{Mg}$ is from 34.3 to $36.2 \mathrm{mg} / \mathrm{kg}$ for the samples TCE-1 to TCE-4.

Sodium (Na) imparts production of energy, transport of amino acids and glucose into the body cells, the average concentration $\mathrm{Na}$ was found to be $77.3 \mathrm{mg} / \mathrm{kg}$ in $T$. chebula aqueous extract ${ }^{39}$.

Potassium $(\mathrm{K})$ is helpful to reduce hypertension and to maintain smooth, cardiac function. In the human body, potassium plays vital roles in many physiological functions, and their deficiency or excess could affect human health 40,41 . The average concentration of $\mathrm{K}$ was $108.2 \mathrm{mg} / \mathrm{kg}$ in $T$. chebula aqueous extract. The range of value obtained for TCE-1 to TCE-4 is $94.960 \mathrm{mg} / \mathrm{kg}$ (TCE-3) to 119.00 $\mathrm{mg} / \mathrm{kg}$ (TCE-2).

Copper $(\mathrm{Cu})$ plays a vital role in the treatment of wounds and prevent inflammation in arthritis and similar diseases ${ }^{42,43}$. The average concentration $\mathrm{Cu}$ was $1.752 \mathrm{mg} / \mathrm{kg}$ in $T$. chebula aqueous extract. The range of values obtained for samples TCE-1 to TCE-4 are $1.6960 \mathrm{mg} / \mathrm{kg}$ (TCE-3) to $1.8202 \mathrm{mg} / \mathrm{kg}$ (TCE-1).

Iron $(\mathrm{Fe})$ is an essential element in the human body for the production of haemoglobin and oxygenation of red blood cells. Fe is needed for a healthy immune system and energy production 44,45 . The average concentration of $\mathrm{Fe}$ was found to be $2.0763 \mathrm{mg} / \mathrm{kg}$ in $T$. chebula aqueous extract. The range of value is from $1.9110 \mathrm{mg} / \mathrm{kg}$ (TCE-3) to $2.3300 \mathrm{mg} / \mathrm{kg}$ (TCE-2).

Manganese (Mn) can help to assist the human body in metabolizing protein, helps in metabolize carbohydrates and treating diabetes ${ }^{47,48}$. The average concentration $\mathrm{Mn}$ was $0.255 \mathrm{mg} / \mathrm{kg}$ in $T$. chebula aqueous extract. The range is between $0.2390 \mathrm{mg} / \mathrm{kg}$ (TCE-3) and $0.2850 \mathrm{mg} / \mathrm{kg}$ for (TCE-1).

Zinc (Zn) deficiency would contribute to arrested sexual maturation, growth retardation and hair loss, delayed wound healing, and emotional disturbance ${ }^{49}$. The average concentration of $\mathrm{Zn}$ was $1.025 \mathrm{mg} / \mathrm{kg}$ in T. chebula aqueous extract. The range of $\mathrm{Zn}$ was found to be between $1.0235 \mathrm{mg} / \mathrm{kg}$ (TCE-4) and $1.0275 \mathrm{mg} / \mathrm{kg}$ (TCE-2).

Based on the above details the essential elements such as $\mathrm{Fe} / \mathrm{Mn} / \mathrm{Zn} / \mathrm{Cu}$ are not present in detectable levels, and hence formulators aiming for fortifying their products with these elements from $T$. chebula are not a preferable choice.

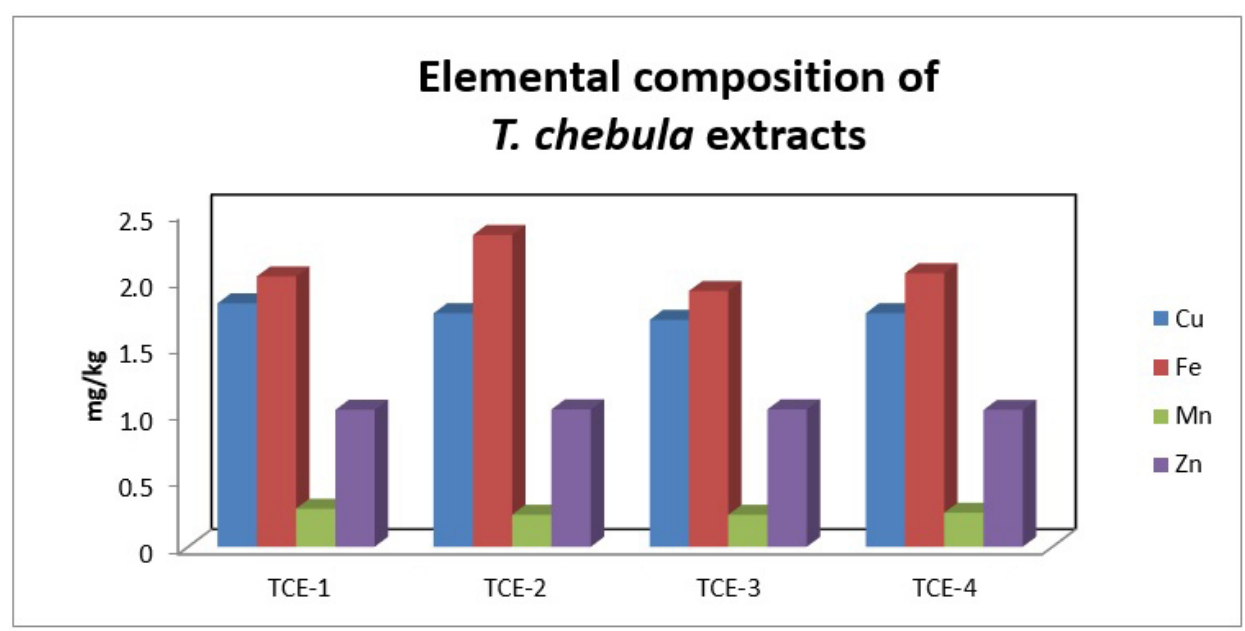

Figure 2. Elemental composition of T. chebula extracts (TCE-1, TCE-2, TCE-3, and TCE-4) [Cu, Fe, Mn, and Zn]. 


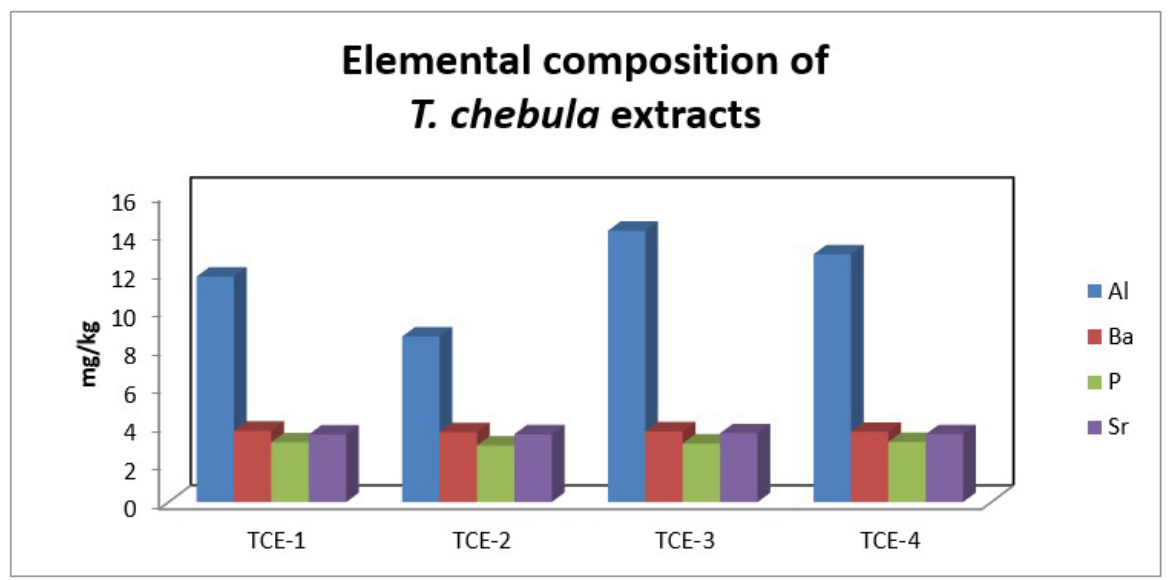

Figure 3. Elemental composition of $T$. chebula extracts (TCE-1, TCE-2, TCE-3, and TCE-4) [Al, Ba, P, and Sr].

Aluminum $(\mathrm{Al})$ is used in the preparation of antacids and food additives. It is used as a component of dental cement and in the preparation of aluminum acetate ear drops ${ }^{50,51}$. Tt is also used to treat ulcers and arrest foul discharges from mucous surfaces. The mean value of $\mathrm{Al}$ is $11.821 \mathrm{mg} / \mathrm{kg}$. The range is from $8.6000 \mathrm{mg} / \mathrm{kg}$ (TCE-2) to $14.097 \mathrm{mg} / \mathrm{kg}$ (TCE-3).

Barium (Ba) is not extensively used element in practice. Of note, "barium meal" and "barium enemas" (barium sulfate) are given to patients suffering from digestive disorders ${ }^{52}$. The action of the stomach and intestines can be seen as the metal's progress through the body is revealed by X-ray imaging. The average concentration of $\mathrm{Ba}$ from samples TCE-1 to TCE-4 is $3.6679 \mathrm{mg} / \mathrm{kg}$, and range is between $3.6330 \mathrm{mg} / \mathrm{kg}$ (TCE-2) and $3.7100 \mathrm{mg} / \mathrm{kg}$ (TCE-1).

Phosphorous (P) is an essential mineral and is required for the healthy formation of bones and teeth, and it is necessary to process many of the foods that we eat ${ }^{53}$. It is also a part of the body's energy storage system and helps to maintain healthy blood sugar levels. The proper heart functioning, cell growth and cell repair require an adequate amount of $\mathrm{P}$ in the body. The average concentration of $\mathrm{P}$ was found to be $3.0537 \mathrm{mg} / \mathrm{kg}$ and the range of values found to be $2.9412 \mathrm{mg} / \mathrm{kg}$ (TCE-2) and $3.1235 \mathrm{mg} / \mathrm{kg}$ (TCE-4).

Strontium ( $\mathrm{Sr}$ ) is used in scientific research to measure the release of neurotransmitters by neurons ${ }^{54}$. $\mathrm{Ca}$ is replaced by $\mathrm{Sr}$, which makes it easier to observe the neuron's response. Radioactive $\mathrm{Sr}$ is used in radio-pharmaceuticals to treat metastatic bone cancer. Human body parts that are experiencing increased bone growth will absorb $\mathrm{Sr}$ instead of $\mathrm{Ca}$. The average concentration of $\mathrm{Sr}$ is $3.5342 \mathrm{mg} / \mathrm{kg}$ and the range of values between $3.5102 \mathrm{mg} / \mathrm{kg}$ (TCE-1) and $3.5765 \mathrm{mg} / \mathrm{kg}$ (TCE-3).

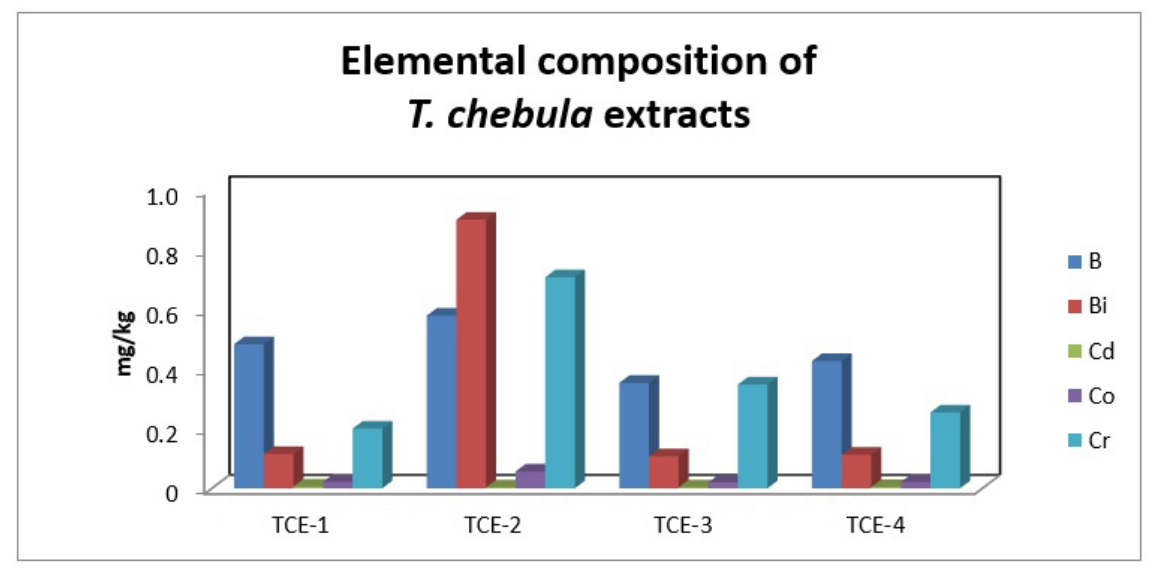

Figure 4. Elemental composition of T. chebula extracts (TCE-1, TCE-2, TCE-3, and TCE-4) [B, Bi, Cd, Co, and $\mathrm{Cr}]$.

Boron (B) is necessary to allow the brain to function properly and can increase mental alertness ${ }^{55}$. Without sufficient amounts of B, bones would slowly weaken and become brittle ${ }^{56}$. The average value of $\mathrm{B}$ was found to be $0.4605 \mathrm{mg} / \mathrm{kg}$. The concentration range was found to be $0.3534 \mathrm{mg} / \mathrm{kg}$ (TCE-3) and $0.5789 \mathrm{mg} / \mathrm{kg}$ (TCE-2).

Bismuth (Bi) is essentially a non-toxic in nature, but prolonged exposure or excessive use may lead to toxicity ${ }^{57}$. This could cause mental confusion, memory loss, stammering during a speech, joint pain, 
or muscle twitching and spasm. It is present in almost a trace amount in the plant material ${ }^{58}$. The average concentration of $\mathrm{Bi}$ is $0.3087 \mathrm{mg} / \mathrm{kg}$, and the range was found to be $0.1074 \mathrm{mg} / \mathrm{kg}$ (TCE-3) and 0.9000 $\mathrm{mg} / \mathrm{kg}$ (TCE-2).

Cadmium $(\mathrm{Cd})$ is an element on which scientists have mixed opinions. While it is undoubtedly believed to be non-essential for plant and animal life processes, some believe $\mathrm{Cd}$ is a trace element with some important role in life processes ${ }^{59,60}$. The average concentration was found to be $0.0041 \mathrm{mg} / \mathrm{kg}$, and the range is between $0.0030 \mathrm{mg} / \mathrm{kg}$ (TCE-2) and 0.0060 $\mathrm{mg} / \mathrm{kg}$ (TCE-1).

Cobalt (Co) is necessary for minimal amounts in all mammals and used to treat several different types of cancer in humans and treat anaemia but the intake of the high amount can cause heart problems ${ }^{61}$. The average concentration Co was $0.030 \mathrm{mg} / \mathrm{kg}$ in
T. chebula aqueous extract. The concentration range of Co was between $0.0200 \mathrm{mg} / \mathrm{kg}$ (TCE-3) and 0.0567 $\mathrm{mg} / \mathrm{kg}$ (TCE-2).

Chromium (Cr) level is low-moderate in all the analyzed samples because the soil where plants were grown has low amounts of $\mathrm{Cr}$. Cr plays a vital role in carbohydrate metabolism, and its deficiency leads to diabetes in human body ${ }^{62} . \mathrm{Cr}$ is a power-providing factor for many enzymatic activities. $\mathrm{Cr}$ deficiency imparts directly to decrease the efficiency of insulin secretion and increases sugar and cholesterol level in the blood ${ }^{63}$. Cr deficiency causes impairment in glucose tolerance factor, leading to insulin resistance. The average concentration of $\mathrm{Cr}$ in $T$. chebula aqueous extract is $0.3774 \mathrm{mg} / \mathrm{kg}$, and the concentration range is found to be $0.2000 \mathrm{mg} / \mathrm{kg}$ (TCE-1) and $0.7076 \mathrm{mg} / \mathrm{kg}$ (TCE-2).

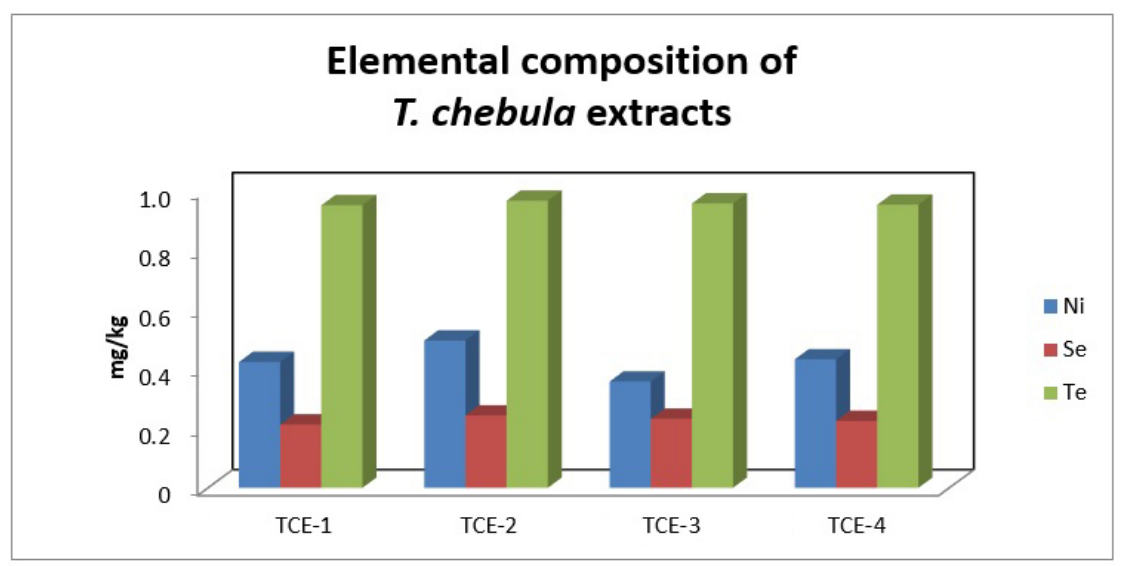

Figure 5. Elemental composition of $T$. chebula extracts (TCE-1, TCE-2, TCE-3, and TCE-4) [Ni, Se, and Te].

Nickel $(\mathrm{Ni})$ is used in the formation of enzymes from bacteria ${ }^{64,65}$. Although many scientists believe that $\mathrm{Ni}$ is necessary for good health, this is not proven yet. People with certain liver and kidney defects are known to have low levels of $\mathrm{Ni}$ in their bodies. Also, excess $\mathrm{Ni}$ in the body is associated with a high incidence of heart disease, thyroid disease and cancer. In both of these cases, the significance of the amount of $\mathrm{Ni}$ needed for the body is unknown. Some scientist also believes that Ni could also affect hormones, cell membranes, and enzymes. The average concentration of $\mathrm{Ni}$ is $0.4276 \mathrm{mg} / \mathrm{kg}$ and the concentration range is $0.3578 \mathrm{mg} / \mathrm{kg}$ (TCE-3) and $0.4960 \mathrm{mg} / \mathrm{kg}$ (TCE-2).

Selenium (Se) is an important element, and its presence in the human body will protect the blood cells from the attack of toxic chemicals ${ }^{66}$. For the production of antibodies in the human body, Se will combine with vitamin $\mathrm{E}$ and synthesis antibodies. Selenium helps to improve the proper functioning of the heart and pancreas. It is also found useful in keeping the human tissues wit elastic nature. Its deficiency in the body could be linked to the cause of leukaemia, arthritis, and other diseases. Many research data reveals that a deficient concentration of
Selenium lesser than the recommended minimum level in the bloodstream could cause a high risk of developing many types of carcinogenic problems. The mean concentration value of Se in T. chebula aqueous extract is $0.2286 \mathrm{mg} / \mathrm{kg}$. The concentration of Se in the extract is between $0.2130 \mathrm{mg} / \mathrm{kg}$ (TCE-1) and $0.2436 \mathrm{mg} / \mathrm{kg}$ (TCE-2).

Tellurium (Te) has no known biological function. Te and Te-based compounds are considered to be mildly toxic and need to be handled with care, although acute poisoning is rare. Te is not reported to be carcinogenic. The average concentration of $\mathrm{Te}$ is $0.9573 \mathrm{mg} / \mathrm{kg}$ and the range is between $0.9514 \mathrm{mg} / \mathrm{kg}$ (TCE-1) and $0.9668 \mathrm{mg} / \mathrm{kg}$ (TCE-2).

Lead $(\mathrm{Pb})$ is highly toxic metal and non-essential element for the human body due to it causes high blood pressure, kidney damage, miscarriages and subtle abortion, brain damage, declined fertility of men through sperm damage, diminished learning abilities of children and disruption of nervous systems 67. The average concentration $\mathrm{Pb}$ was $0.670 \mathrm{mg} / \mathrm{kg}$ in $T$. chebula aqueous extract. The concentration range of $\mathrm{Pb}$ in all four samples is between $0.6323 \mathrm{mg} / \mathrm{kg}$ (TCE-3) and $0.6874 \mathrm{mg} / \mathrm{kg}$ (TCE-1). 


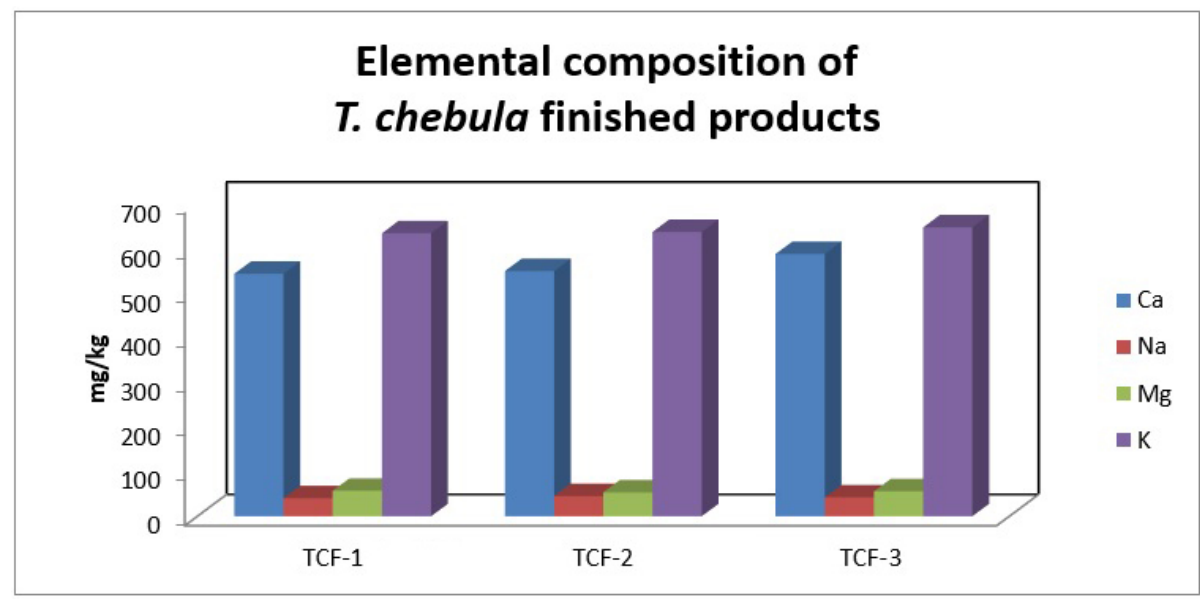

Figure 6. Elemental composition of T. chebula finished products (TCF-1, TCF-2, and TCF-3) [Ca, $\mathrm{Na}, \mathrm{Mg}$, and $\mathrm{K}]$.

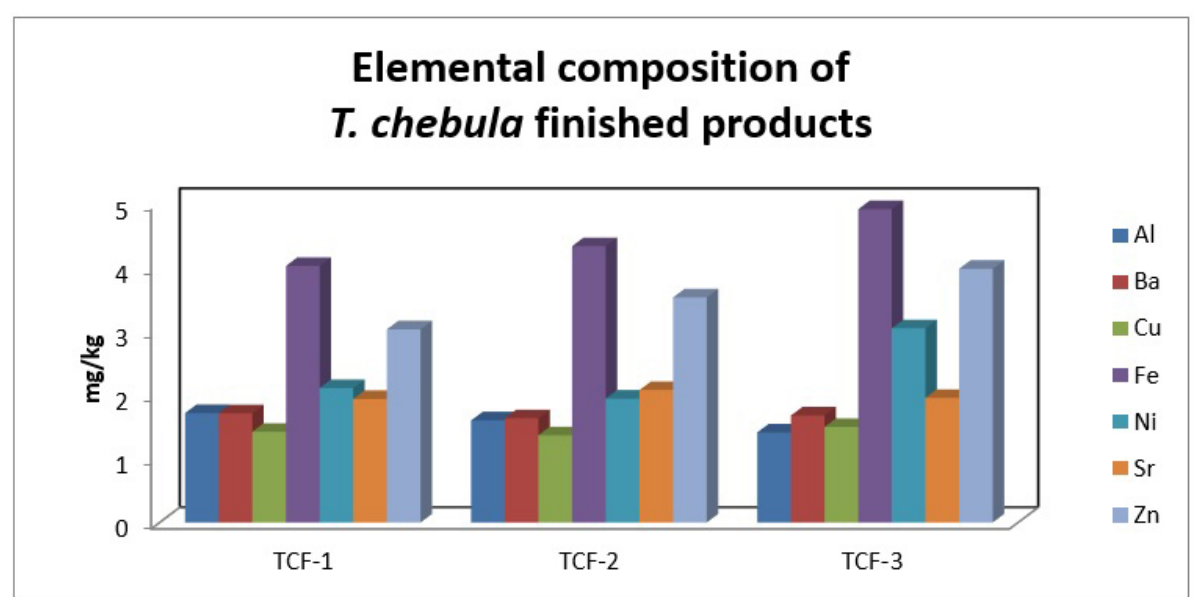

Figure 7. Elemental composition of T. chebula finished products (TCF-1, TCF-2, and TCF-3) [Al, Ba, Cu, Fe, Ni, Sr, and $\mathrm{Zn}$ ].

The finished products of $T$. chebula consist of slightly different elemental composition in comparison with the aqueous extract of $T$. chebula because some of the elements are an absent or shallow concentration in the finished products. Atmospheric conditions, pollution, the season of sample collection, age of the plant, and soil conditions are the major environmental factors that could affect the concentration of elements as it varies from plant to plant and region to region.

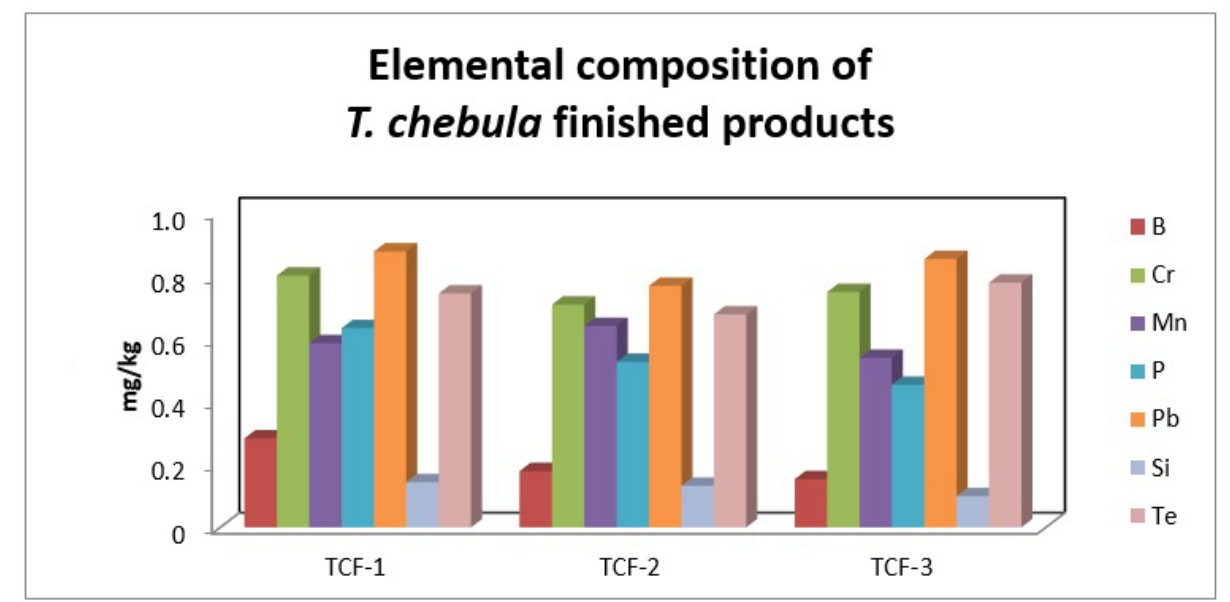

Figure 8. Elemental composition of T. chebula finished products (TCF-1, TCF-2, and TCF-3) [B, Cr, Mn, P, Pb, Si, and Te]. 
Trace elements with less toxicity in nature would play both restorative and protective roles in skirmishing diseases. Many trace elements could be well exploited for the development of preventive medicinal aspects and combating many diseases.

\section{Conclusion}

Determination of macro and microelements in T. chebula aqueous extracts and finished products was performed using ICP-OES. The macro elements $(\mathrm{Ca}$, $\mathrm{Mg}, \mathrm{Na}$, and $\mathrm{K}$ ) were found to be inappreciable concentration and low or fewer concentrations of toxic elements of Lead and cadmium in the extracts of T. chebula. Hence, the use of these extracts is considered to be safe for the finished products. The details of essential elements, toxic elements would be also helpful for the product manufacturers to specify the levels of these elements in the quality specifications. The different concentration of same elements with different $T$. chebula extracts is due to the attribution of plant collection, which in turn depends on the soil in which the plant was grown in, age of the plant, climatic conditions, the season of harvesting, etc. However, in order to develop a stronger basis for appreciating the curative effects of medicinal plants, there is a need to study the effect of soil and climatic conditions on the elemental contents of these medicinal plants. T. chebula extracts and finished products can be employed in the design of new ayurvedic drugs either alone or in combination with other herbal extracts for the treatment and control of many diseases.

\section{References}

1- I.S. Grover, S. Bala, Antimutagenic activity of Terminalia chebula (Myrobalan) in Salmonella typhimurium, Indian J Exp Biol, 1992, 30(4), 339-341.

2- V. Sheetal, S.P. Singh, Current and future status of herbal medicines, Veterinary World, 2008, 1(11), 347-350.

3- P.K Saha, P.H. Patr, N.R. Pradhan, D. Radharaman, D. Shyamal, T.K. Mandal, Effect of Terminalia chebula and Terminalia belerica on wound healing in induced dermal wounds in rabbits, PharmacologyOnLine, 2011, 2, 235-241.

4- Y. Sato, H. Oketani, K. Singyouchi, K.T. Ohtsubo, M. Kihara, H. Shibata, P. Higuti, Phytopharmacological activities of Terminalia species, Biol Pharm Bull, 1997, 20(4), 401-404.

5- H.Y. Cheng, T.C. Lin, K.H. Yu, C.M. Yang, C.C. Lin, Antioxidant and free radical scavenging activities of Terminalia chebula, Biol Pharm Bull, 2003, 26(9), 1331-1335.

6- A.H.N. Jeong, C.Y. Kim, J.S. Lee, T.G. Kim, S.H. Kim, C.K. Lee, B. Lee, C.G. Shim, H. Hoon, J. Kim, Inhibition of HIV-1 integrase by galloyl glucoses from Terminalia chebula and flovonol glycoside gallates from euphorbia pekinensis, Planta Medica, 2002, 68(5), 457-459.

7- J.N. Kolla, N.M. Kulkarni, R.R. Kura, S.K.R. Theepireddy, Terminalia chebula Retz. - an important medicinal plant, Herba Polonica, 2017, 63(4), 45-56.

8- C.P. Thakur, B. Thakur, S. Singh, P.K. Sinha, S.K. Sinha, The ayurvedic medicines haritaki, amala and bahira reduce cholesterol-induced atherosclerosis in rabbits, Int J Cardiol, 1988, 21(2), 167-175.

9- N.M. Gandhi, C.K.K. Nair, Radiation protection by Terminalia chebula: some mechanistic aspects, Mol Cell Biochem, 2005, 277(1-2), 43-48

10- B.D. Miglani, P. Sen, R.K. Sanyal, Purgative action of oil obtained from Terminalia chebula, Indian J Med Res, 1971, 59(2), 281-283.

11- J. Gao, O.S. Ajala, C.Y. Wang, H.Y. Xu, J. H. Yao, H.P. Zhang, A. Jukov, C.M. Ma, Comparison of pharmacokinetic profiles of Terminalia phenolics after intragastric administration of the aqueous extracts of the fruit of Terminalia chebula and a Mongolian compound medicine-Gurigumu-7, J Ethnopharmacol, 2016, 5(185), 300-309.

12- C.G. Prakash, Biological and pharmacological properties of Terminalia chebula Retz. (Haritaki) - an overview, Int J Pharm Sci, 2012, 4(3), 62-68.

13- A.G. Jagtap, S.G. Karkera, Potential of the aqueous extract of Terminalia chebula as an anticaries agent, J Ethnopharmacol, 1999, 68 (1-3), 299-306.

14- P. Sharma, T. Prakash, D. Kotresha, M.A. Ansar, U.R. Sahrm, B. Kumar,J. Debnath, D. Koli, Antiulcerogenic activity of Terminalia chebula fruit in experimentally induced ulcer in rats, Pharm Biol, 2011, 49(3), 262-268.

15- A. Saleem, M. Husheem, P. Harkonen, K. Pihlaja, Inhibition of cancer cell growth by crude extract and the phenolics of Terminalia chebula retz. fruit, J Ethnopharmacol, 2002, 81(3), 327-336.

16- H.Y. Cheng, T.C. Hua-Yew Cheng Lin, K.H. Ta-Chen Lin Yu, C.M. Kuo-Hua Yu Yang, C.C. Chien-min Yang Lin CC, Antioxidant and free radical scavenging activities of Terminalia chebula, Biol Pharm Bull, 2003,26(9), 1331-1335.

17- K.R. Aneja, C. Sharma, R. Joshi, Antimicrobial activity of Terminalia arjuna Wight \& Arn.: an ethnomedicinal plant against pathogens causing ear infection, Braz J Otorhinolaryngol, 2012, 78(1), 68-74.

18- J. Lee, Y.H. Nho, S.K. Yun, Y.S. Hwang, Use of ethanol extracts of Terminalia chebula to prevent periodontal disease induced by dental plaque bacteria, BMC Complement Altern Med, 2017, 17(1), 113. 
19- F. Malekzadeh, H. Ehsanifar, M. Shahamat, M. Levin, R.R. Colwell, Antibacterial activity of black Myrobalan (Terminalia chebula Retz) against Helicobacter pylori, Int J Antimicrob Agents, 2001, 18(1), 85-88.

20- S.N. Gaidhani, G.S. Lavekar, A.S. Juvekar, S. Sen, S. Arjun, K. Suman, In-vitro anticancer activity of standard extracts used in ayurveda, Pharmacogn Mag, 2009, 5(20), 425-429.

21- R. Ahuja, N. Agrawal, A. Mukerjee, Evaluation of anticancer potential of Terminalia chebula fruits against Ehrlich Ascites carcinoma induced cancer in mice, J Sci Innov Res, 2013, 2(3), 549-554.

22- Amir R. Afshari, Hamid R. Sadeghnia, H amid Mollazadeh, A review on potential mechanisms of Terminalia chebula in Alzheimer's disease, Adv Pharmacol Sci, 2016, 2016 (1), 1-14.

23- S. Kaur, I.S. Grover, M. Singh, S. Kaur, Antimutagenicity of hydrolyzable tannins from Terminalia chebula in Salmonella typhimurium, Mutat Res., 1998, 419(1-3), 169-179.

24- T.Y. Shin, H.J. Jeong, D.K. Kim, S.H. Kim, J.K. Lee, D.K. Kim, B.S. Chae, J.H. Kim, H.W. Kang, C.M. Lee, K.C. Lee, S.T. Park, E.J. Lee, J.P. Lim, H.M. Kim, Y.M. Lee, Inhibitory action of water-soluble fraction of Terminalia chebula on systemic and local anaphylaxis, J Ethnopharmacol, 2001, 74(2), 133-140.

25- M. Ajaib, Z. Khan, N. Khan, M. Wahab, Ethnobotanical studies on useful shrubs of District Kotli, Azad Jammu \& Kashmir, Pakistan, Pak J Bot, 2010, 42(3), 1407-1415.

26- F. Haq, H. Ahmad, M. Alam, Traditional uses of medicinal plants of Nandiar Khawarr (District Battgram) catchment, Pak. J Med Plants Res, 2011, 5(1), 39-48.

27- K.Y. Khan, M.A. Khan, R. Niamat, M. Munir, H. Fazal, P. Mazari, P.N. Seema, T. Bashir, A. Kanwal, S.N. Ahmed, Element content analysis of plants of genus Ficus using atomic absorption spectrometer, Afr J Pharm Pharmacol, 2011, 5(3), 317-321.

28- T. Starlin, P. Ragavendran, C. Arulraj, P. Chellaperumal, V.K. Gopalakrishnan, Element and functional group analysis of Ichnocarpus frutescens R.Br. (apocynaceae), Indian J Pharm Pharm Sci, 2012, 4(5), 343-345.

29- D.N. Zull, Disorders of potassium metabolism, Emerg Med Clin North Am, 1989, 7(4), 771-794.

30- I. Hameed, G. Dastagir, F. Hussain, Nutritional and elemental analyses of some selected medicinal plants of the family Polygonaceae, Pak J Bot, 2008, 40(6), 2493-2502.

31- A. Ghosh, B.P. Pakhira, A. Tripathy, D. Ghosh, Male contraceptive efficacy of polyherbal formulation, contracept-TM, composed of aqueous extracts of Terminalia chebula fruit and Musa balbisiana seed in rat, Pharm Biol, 2017, 55(1), 2035-2042.

32- G.M. Kumar, I. Neelam, A. Ajitha, V. MaheshwaraRao, inductively coupled plasma atomic absorption spectroscopy: an overview, Int J Pharm Res Anal, 2014, 4(8), 470-477.

33- R. Garcia, A.P. Baez, Atomic Absorption Spectroscopy, ed. by Muhammad Akhyar Farrukh; InTech; Croatia, 2012, pp. 1-12.

34- P.B. Beeson, Changes in medical therapy during the past half-century, Medicine (Baltimore), 1980, 59(2), 79-99.

35- J.A. Sunyecz, The use of calcium and vitamin $\mathrm{D}$ in the management of osteoporosis, Ther Clin Risk Manag, 2008, 4(4), 827-836.

36- I.S. Wright, The nomenclature of blood clotting factors, Can Med Assoc J, 1962, 86(8), 373-374.

37- C. Justet, S. Chifflet, J.A. Hernandez, Calcium oscillatory behavior and its possible role during wound healing in bovine corneal endothelial cells in culture, BioMed Res Int, 2019, 2019, $1-16$.

38- G. Faúndez, M. Troncoso, P. Navarrete, G. Figueroa, Antimicrobial activity of copper surfaces against suspensions of Salmonella enterica and Campylobacter jejuni, BMC Microbiol, 2004, 4(19), 19.

39- K. J. Ullrich, G. Rumrich, S. Klöss, Sodium dependence of the amino acid transport in the proximal convolution of the rat kidney, Pflügers Archiv, 1974, 351(1), 49-60.

40- S. Shan, X. Huang, M.H. Shah, A.M. Abbasi, Evaluation of polyphenolic content and antioxidant activity in edible wild fruits, BioMed Res Int, 2018, 2019, 1381989.

41- N. Banu, V. Patel, J.P.N. Chansouria, O.P. Maliiotra, K.N. Udupa, Role of amalaki (Officinalis emblica Linn) rasayana in experimental peptic ulcer, J Res Educ Indian Med, 1987, 1(1), 29-34.

42- S. Bagde, D. Biswas, A review on some selected traditional Indian medicinal plants of immunomodulatory potential and their therapeutic use in rheumatoid arthritis, Int J Pharm Sci Res, 2019, 10(5), 2087-2100.

43- N.S. Rajurkar, B.M. Pardeshi, Analysis of some herbal plants from India used in the control of diabetes mellitus by NAA and AAS techniques, Appl Radiat Isot, 1997, 48(8), 1059-1062.

44- G. Borkow, Using copper to improve the wellbeing of the skin, Curr Chem Biol, 2014, 8(2), 89-102.

45- B. Mittal, A. Meenakshi, Sharma, V.K. Gothecha, Phytochemical and pharmacological activity of Rauvolfia Serpentina - a review, Int J Ayurvic Herb Med, 2012, 2(3), 427-434.

46- C.P. Gupta, Role of iron (Fe) in body, IOSR J Appl Chem, 2014, 7 (11), 38-46. 
47- J.G. Penland, The importance of boron nutrition for brain and psychological function, Biol Trace Elem Res, 1998, 66(1-3), 299-317.

48- P. Chen, J. Bornhorst, M. Aschner, Manganese metabolism in humans, Front Biosci (Landmark Ed), 2018, 23, 1655-1679.

49- H.T.T. Ha, S. Leal-Ortiz, K. Lalwani, S. Kiyonaka, I. Hamachi, S.P. Mysore, J.M. Montgomery, C.C. Garner, J.R. Huguenard, S.A. Kim, Shank and zinc mediate an AMPA receptor subunit switch in developing neurons, Front Mol Neurosci, 2018, 11, 1-30.

50- M. Saeed, H. Khan, M.A. Khan, F. Khan, S.A. Khan, N. Muhammad, Quantification of various metals accumulation and cytotoxic profile of aerial parts of Polygonatum verticillatum, Pak J Bot, 2010, 42(6), 3995-4002.

51- A. Ali, Hamiduddin, M. Zaigham, Shibb-EYamani (Alum) a unique drug and its utilization in Unani medicine: a physicochemical and pharmacological review, Int J Res Ayurveda Pharm, 2017, 8(2), 17-22.

52- E.D. Cook, L.L. Newman, A Complete Guide to Clinical Management, Cancer Prevention and Healthy Aging, ed. by P.P. Coll, Springer; Switzerland AG, 2019, 189-199.

53- M.S. Calvo, A.J. Moshfegh, K.L. Tucker, Assessing the health impact of phosphorus in the food supply: issues and considerations, Adv Nutr, 2014, 5(1), 104-113.

54- D.B. Lamotte, G.S. Bhumbra, J.D. Foster, M. Beato, P. Ascher, Segregation of glutamatergic and cholinergic transmission at the mixed motoneuron Renshaw cell synapse, Sci Rep, 2017, 4037, 1-17.

55- M.S. Koo, T. Ozawa, R.A. Santos, K.R. Lamborn, A.W. Bollen, D.F. Deen, S.B. Kahl, Synthesis and comparative toxicology of a series of polyhedral borane anion-substituted tetraphenyl porphyrins, J Med Chem, 2007, 50(4), 820-827.

56- F. Inam, S.S. Deo, N.S. Kadam, R.P. Mahashabde, Comparative account of heavy metal analysis of selected plant species by ICP-
AES, Res J Pharm Biol Chem Sci, 2012, 3(2), 57-63.

57- A. Baiyisaiti, Y. Wang, X. Zhang, W. Chen, R. Qi, Rosa rugosa flavonoids exhibited PPAR $\alpha$ agonist-like effects on severe genetic hypertriglyceridemia of mice, $\mathrm{J}$ Ethnopharmacol, 2019, 240, 111952.

58- R.A. Anderson, Nutritional factors influencing the glucose/insulin system: chromium, J Amer Coll Nutr, 1997, 16(5), 404-410.

59- T. Schmidt, G.H. Schlegel, Nickel and cobalt resistance of various bacteria isolated from soil and highly polluted domestic and industrial wastes, FEMS Microbiol Lett, 1989, 62(5), 315-328.

60- L. Jouybari, G.N.M. Saei, A. Sanagoo, F. Kiani, F. Sayehmiri, K. Sayehmiri, D.A. Hasanpour, Toxic elements as biomarkers for breast cancer: a meta-analysis study, Cancer Man Res, 2018, 10, 69-79.

61- M. Sambi, L. Bagheri, M.R. Szewczuk, Current challenges in cancer immunotherapy: multimodal approaches to improve efficacy and patient response rates, J Oncol, 2019, 2019, $1-12$.

62- D. Sharma, S. Verma, S. Vaidya, K. Kalia, V. Tiwari, Recent updates on GLP-1 agonists: current advancements and challenges, Biomed Pharmcother, 2018, 108, 952-962.

63- G. Wilcox, Insulin and insulin resistance, Clin Biochem Rev, 2005, 26(2), 19-39.

64- M.J. Maroney, S. Ciurli, Nonredox nickel enzymes, Chem Rev, 2014, 114(8), 4206-4228.

65- S. Kumar, A.V. Trivedi, Review on the role of nickel in the biological system, Int J Curr Microbiol App Sci, 2016, 5(3), 719-727.

66- M.J. De Oliveira, G. Boué, S. Guillou, F. Pierre, J.M. Membré, Estimation of the burden of disease attributable to red meat consumption in France: influence on colorectal cancer and cardiovascular diseases, Food Chem Toxicol, 2019, 130, 174-186.

67- P. Aggarwal, R. Handa, J.P. Wali, Acute poisoning-management guidelines, J Indian Acad Clin Med, 2000, 5(2), 142-147. 